\title{
GENE EXPRESSION PROGRAMMING APPLICATION FOR PREDICTION OF ULTIMATE AXIAL STRAIN OF FRP-CONFINED CONCRETE
}

Scientific paper/ Znanstveni rad

Iman Mansouri

(Received: 28 April 2018; accepted: 7 June 2018)

Birjand University of Technology, Department of Civil Engineering, Assistant Professor

Hazi Mohammad Azmathulla

Fiji National University, Department of Civil Engineering, PhD

Jong Wan $\mathrm{Hu}$

Incheon National University, Department of Civil and Environmental Engineering, Assistant Professor

Corresponding author: jongp24@inu.ac.kr

\begin{abstract}
The last three decades have seen increasing applications of fiber-reinforced polymer materials in structural engineering because of their many advantages over traditional strengthening and reinforcing materials. On the other hand, soft computing approaches have recently been widely used to model human activity in many areas of civil engineering applications. This paper presents the use of genetic expression programming as a tool to predict the ultimate axial strain of fiber-reinforced polymer-confined concrete. A large experimental data set (219) of these tests is collected from published literature. The prediction of the proposed new genetic expression programming-based model was compared with the results obtained using the existing analytical equations proposed in the current literature. In this paper, attempts were made to present a complete review of genetic expression programming in structural engineering. Good agreement between the experimental data and predicted results is obtained.
\end{abstract}

Keywords: fiber-reinforced polymer (FRP); ultimate axial strain; genetic expression programming (GEP); database

\section{PRIMJENA PROGRAMIRANJA GENSKIM IZRAZOM ZA PREDVIĐANJE MAKSIMALNE UZDUŽNE DEFORMACIJE BETONA OVIJENOG FRP-OM}

\begin{abstract}
Sažetak: Posljednja tri desetljeća svjedoče intenzivnijim primjenama polimernih materijala ojačanih vlaknima u konstrukcijskom inženjerstvu, zbog svojih prednosti u odnosu na tradicionalne ukrutne i armaturne materijale. $S$ druge strane, neki računalni pristupi su široko korišteni za modeliranje ljudskih aktivnosti u više područja s primjenom u građevinarstvu. Ovaj rad predstavlja primjenu programiranja genskim izrazom, kao alata za predviđanje vršne uzdužne deformacije betona ovijenog polimerima i ojačanim vlaknima. Opsežna baza eksperimentalnih podataka (219) spomenutih ispitivanja prikupljena je iz objavljene literature. Predviđanje predloženog novog modela, zasnovanog na programiranju genetičkim izrazom, uspoređeno je s rezultatima dobivenima korištenjem postojećih analitičkih izraza, predloženih u trenutačnoj literaturi. U ovome radu pokušalo se pokazati cjeloviti pregled programiranja genetičkim izrazom u građevinarstvu. Dobiveno je dobro slaganje između eksperimentalnih podataka i rezultata predviđanja.
\end{abstract}

Ključne riječi: polimer ojačan vlaknima (FRP); maksimalna uzdužna deformacija; programiranje genetičkim izrazom (GEP); baza podataka

Mansouri, I, Azmathulla, H M, Wan Hu, J 


\section{INTRODUCTION}

In the last two decades, the civil engineering community has witnessed a rapid growth of interest in the compressive behavior of FRP-confined concrete. It is now well understood that the confinement of concrete with fiber-reinforced polymer (FRP) composites can significantly increase concrete strength and deformability. A variety of uniaxial compression tests were carried out on both large- and small-scale FRP confined concrete specimens with different cross sections (circular, square, rectangular, and elliptical); a relevant contribution for the performance evaluation of large-scale specimens can be found in [1]. Further experimental investigations focused on full-scale reinforced concrete members confined with FRP and subjected to combined axial loads and cyclic flexures [2]. These experimental tests were all focused on evaluating the suitability of using FRP jackets as a seismic retrofit technique for nonductile rectangular or circular columns [3-7].

The conventional stress-strain models of FRP-confined concrete fall into two main categories: design-oriented models and analysis-oriented models. The design-oriented models are generally in closed-form equations directly derived from dataset results, treating FRP-confined concrete as a single composite material, and are thus simple and convenient to apply in design [8]. By contrast, the analysis-oriented models treat the FRP jacket and the concrete core separately, and predict the behavior of FRP-confined concrete by an explicit account of the interaction between the FRP jacket and the confined concrete core [8-11].

In this study, a published database containing 219 experimental test results is used to develop a designoriented model using gene expression programming (GEP). The GEP approach is capable of dealing with complex problems that contain a large number of uncertainties. GEP was recently devised by various researchers for developing complex relations between experimental data as an efficient alternative to traditional regression and machine learning methods (e.g., artificial neural networks and ANN) [12-14]. GEP has been used by some researchers to solve engineering problems [15-23].

This article aims to apply gene expression programming to develop new empirical equations in order to predict the ultimate strain. The important factors that influence the overall behavior of FRP-confined concrete are then discussed. In the final part of this study, a new design-oriented model is developed, and use of the database to predict the ultimate strain of FRP-confined concrete is presented.

\section{CONFINEMENT MECHANISM}

The concrete behaves elastically when subjected to a low level of longitudinal strain. By using Poisson's ratio, the transverse strain can be obtained. By increasing the load, cracks start to form, leading to a large increase in the lateral strain. The transverse strain of the confined specimens is equal to the strain in the FRP jacket (based on deformation compatibility). The propensity of concrete to expand after cracking and the radial stiffness of the confining jacket to maintain the concrete dilatation are considered to be two important parameters that affect the concrete confinement [24].

The confinement action exerted by the FRP on the concrete core is of the passive type, that is, it arises as a result of the lateral expansion of concrete under an axial load. As the axial stress increases, the corresponding lateral strain increases, and the confining device develops a tensile hoop stress balanced by a uniform radial pressure that reacts against the concrete lateral expansion. As the FRP shell is subjected to tension along its hoop direction, the confining pressure $(p)$ increases proportionally with the lateral expansion until the eventual failure of the system when the FRP shell ruptures (Figure 1).

Assuming deformation compatibility between the confining shell and the concrete surface, the lateral confining pressure applied to concrete by the FRP shell at the ultimate strain (pu) is given as follows:

$$
p_{u}=\frac{2 E_{f} t_{f} \varepsilon_{f}}{D}
$$

In which Ef is the elastic modulus of the fibers, tf is total nominal thickness of the fibers, ${ }^{\varepsilon_{f}}$ is the ultimate tensile strain of the fibers, and $D$ is the diameter of the concrete core. 


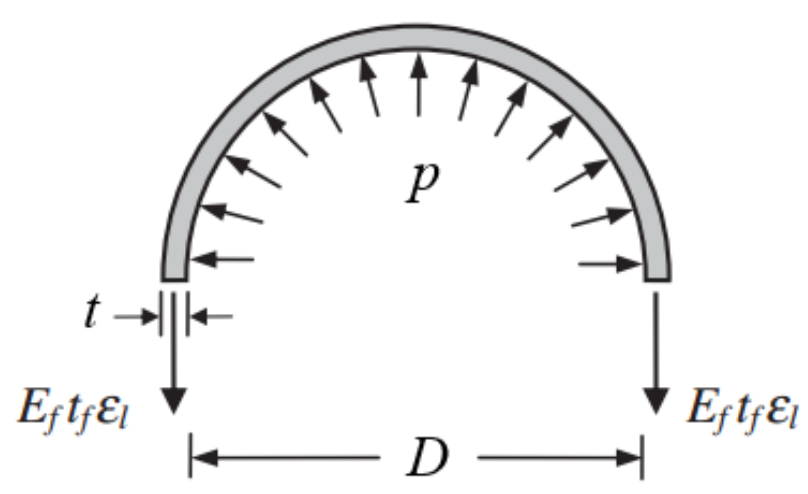

Figure 1 Scheme of confinement action

Several studies [25-32] reported that the ultimate strain measured on the FRP shell at the time of FRP hoop rupture, ${ }^{\varepsilon_{h, r u p}}$, is lower than the ultimate tensile strain of the fibers $\varepsilon_{f}$ or FRP material ${ }^{\varepsilon_{r u p}}$. To establish the relationship between the hoop rupture strain of the FRP shell ${ }_{h, \text { rup }}$ to the ultimate tensile strain of the material $\varepsilon_{f}$, a strain reduction factor $k_{\varepsilon}$ was proposed in [31]:

$$
\varepsilon_{h, r u p}=k_{\varepsilon} \varepsilon_{f}
$$

The actual lateral confining pressure at the ultimate strain (pu,a) was defined in [27] as follows:

$$
p_{u, a}=\frac{2 E_{f} t_{f} \varepsilon_{h, r u p}}{D}
$$

Various influential parameters that affect the debonding resistance, including the unconfined concrete strength $f_{c o}^{\prime}$, unconfined concrete strain $\varepsilon_{c o}$, hoop rupture strain $\varepsilon_{h, r u p}$, and FRP confinement stiffness $\left(\mathrm{k}_{\mathrm{conf}}=2 \mathrm{Ef \textrm {tf }} / \mathrm{D}\right)$ are considered as input parameters to the GEP to predict the ultimate axial strain of FRP-confined concrete $\left({ }^{{ }^{c u}}\right)$.

\subsection{Database for FRP-confined concrete}

An extensive database including all data collected from the literature was created to determine the ultimate axial strain of FRP-confined concrete ( ${ }^{\varepsilon_{c u}}$ ). The database contains test results of 219 FRP-confined concrete experiments and is summarized in Table 1.

\section{PROPOSED MODEL USING GEP}

Here, a mathematical model is developed by the authors. For this problem, the fitness $\mathrm{fi}$ of an individual program $\mathrm{i}$ is measured by

$$
f_{i}=\sum_{j=1}^{C_{t}}\left(M-\left|C_{(i, j)}-T_{j}\right|\right)
$$

Where $M$ is the range of selection, $C_{(i, j)}$ is the value returned by the individual chromosome $i$ for fitness case $j$ (out of $C_{t}$ fitness cases), and $T_{j}$ is the target value for fitness case $j$. If $\left|C_{(i, j)}-T_{j}\right|$ (the precision) $\leqq 0.01$, then the precision $=0$, and $f_{i}=f_{\max }=C_{t} M$. In this case, $M=100$ is used, and therefore $f_{\max }=1000$. The advantage of this kind of fitness function is that the system can find the optimal solution by itself. 
In the second step, the set of terminals $T$ and the set of functions $F$ are selected to make the chromosomes. In this paper, the terminal set includes single independent variables, i.e., $T=\left\{\varepsilon_{c u}\right)=f\left(f_{c o}^{\prime}\right),\left(\varepsilon_{c o}\right),\left(\varepsilon_{h, \text { rup }}\right)$ and $\left.\left(k_{\text {conf }}=2 E_{f} t_{f} / D\right)\right\}$. In this study, five basic arithmetic operators $\left(+,-,{ }^{*}, I\right.$, Power) were used as connecting parameters.

Third, the length of the head and the number of genes is selected. Here, the chromosomes contain three numbers of genes with head length $h=8$ and gene length $t=9$, giving the length of the chromosome as 30 .

The fourth major step is to choose the linking function. In this paper, addition is employed as a linking function, and it is observed that linking the sub-ETs by addition gives better fitness (Eq. 4) values. The final step is to choose the set of genetic operators that cause variations, and their rates. A composition of all genetic operators (mutation, transposition, and crossover) is employed toward this goal.

A calibration of the GEP model is performed based on the 291 collected data sets. (For the range of this data, see Table A1). Among the 291 data sets, $20 \%$ of the data sets are used to test the GEP model, while the remaining $80 \%$ are employed to train the GEP model.

The best of generation singular, chromosomes 30 , has a fitness of 677.99 for $\varepsilon_{c u}$. The explicit equation obtained from the GEP model for $\varepsilon_{c u}$ is shown in Eq. (5), and the corresponding expression trees are illustrated in Figure 2.

$$
\begin{aligned}
\varepsilon_{c u} & =\left(\frac{\varepsilon_{c o}+\varepsilon_{h, r u p}}{\varepsilon_{h, r u p}+f_{c o}^{\prime}}\right)\left(\sqrt{k_{c o n f}}-f_{c o}^{\prime} \varepsilon_{h, r u p}\right)+\left(\frac{2 \varepsilon_{c o}+\varepsilon_{h, r u p}}{9.48+f_{c o}^{\prime}}\right)\left(k_{c o n f} \varepsilon_{h, r u p}-\varepsilon_{c o}-7.42\right)+ \\
& +\left(\frac{\varepsilon_{h, r u p}+1.96}{1.346}\right)\left(\varepsilon_{c o}-\varepsilon_{h, r u p}^{2}\right)
\end{aligned}
$$

From an engineering design point of view, the investigation would be remarkably strengthened if the elaboration of existing models and observed behavior of samples (within the framework of GEP) were both utilized toward more accurate and simple design equations.

$$
\text { Sub-ET } 1
$$
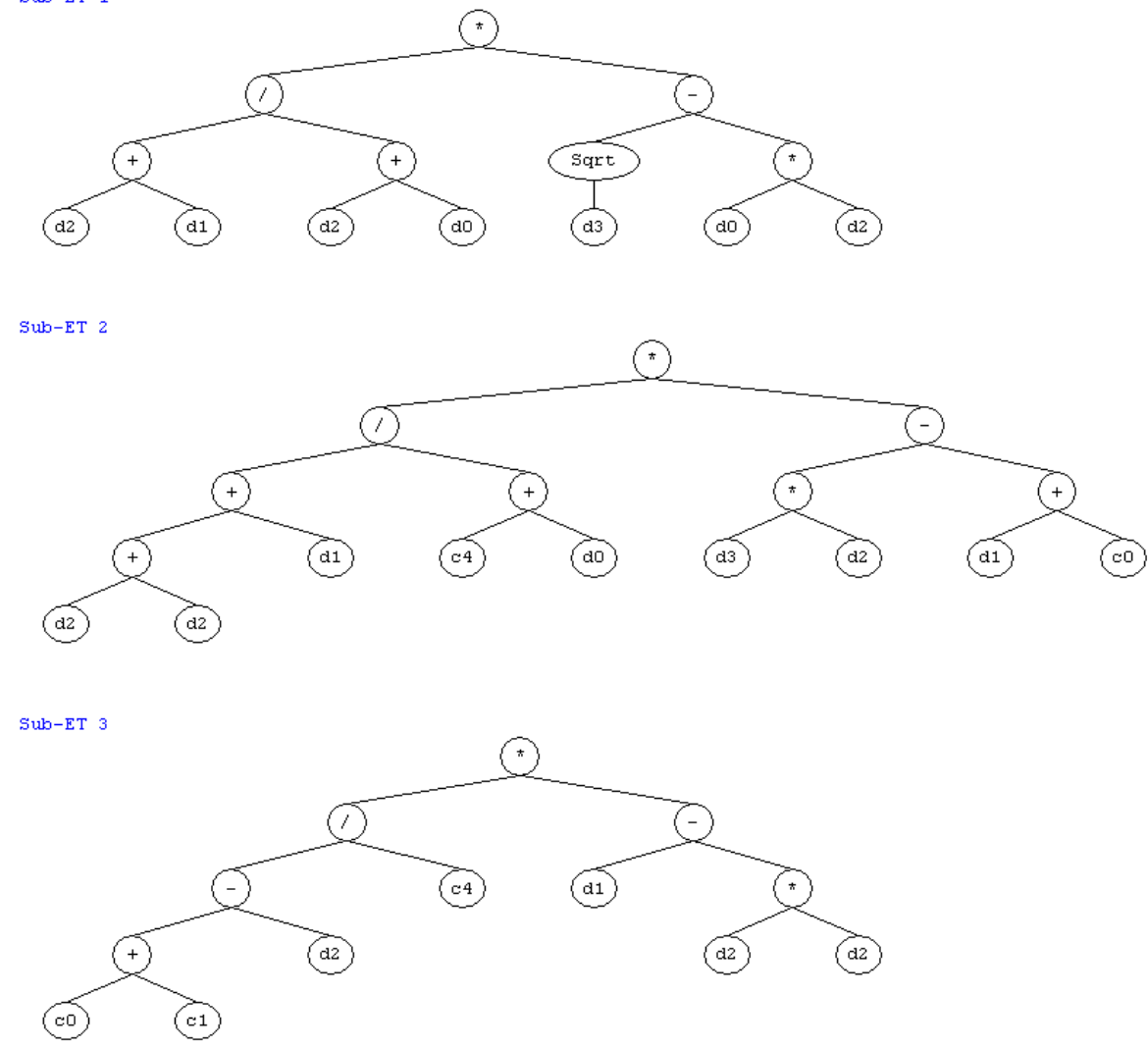

Figure 2 Expression tree for GEP formulation (three subtrees) 


\section{EXISTING FRP-CONFINED CONCRETE MODELS}

Several theoretical models listed in Table 1 were previously developed to predict the ultimate axial strain of FRPconfined concrete. A review of the existing models applicable to EBFRP-to-concrete bonded joints can be found in [29].

\section{Table 1 Some existing models}

\begin{tabular}{lll}
\hline \multicolumn{1}{c}{ Model } & \multicolumn{1}{c}{ Equation } & Reference \\
\hline Ozbakkaloglu & $\varepsilon_{c u}=c_{2} \varepsilon_{c o}+0.27\left(\frac{k_{c o n f}}{f_{c o}^{\prime}}\right)^{0.9} \varepsilon_{h, r u p}^{1.35}$ & [28] \\
and Lim & $c_{2}=2-\frac{f_{c o}^{\prime}-20}{100} \geq 1$ \\
Teng et al. & $\varepsilon_{c u}=\varepsilon_{c o}\left(1.75+6.5 \rho_{K}^{0.8} \rho_{\varepsilon}^{1.45}\right)$ \\
& $\rho_{K}=\frac{k_{c o n f}}{f_{c o}^{\prime} / \varepsilon_{c o}}, \rho_{\varepsilon}=\varepsilon_{h, \text { nup }} / \varepsilon_{c o}$
\end{tabular}

Fardis and

Khalili

$$
\varepsilon_{c u}=0.002+0.0005 k_{\text {conf }} / f_{c o}^{\prime}
$$

Berthet et al.

$$
\varepsilon_{c u}=\varepsilon_{c o}+\frac{\varepsilon_{h, r u p}-v_{c} \varepsilon_{c o}}{\mu_{t u}}, v_{c} \text { is Poisson's ratio of concrete }
$$

$$
\mu_{t u}=\frac{1}{\sqrt{2}}\left(\frac{k_{c o n f}}{f_{c o}^{\prime 2}}\right)^{-2 / 3}
$$

Tamuzs et al.

$$
\varepsilon_{c u}=\varepsilon_{c o}+\frac{\varepsilon_{h, r u p}-v_{c} \varepsilon_{c o}}{\mu_{t u}}, v_{c} \text { is Poisson's ratio of concrete }
$$

$$
\begin{aligned}
\mu_{t u}=5.9\left(\frac{k_{c o n f}}{f_{c o}^{\prime 2}}\right)^{-0.65} \\
\varepsilon_{c u}=\left(\varepsilon_{c o}+b\right)\left(\varepsilon_{c o}{ }^{c}+\frac{k_{c o n f}}{f_{c o}^{\prime}}\left(2 \varepsilon_{c o}+b\right)\right)
\end{aligned}
$$

Lim et al.

$$
\mathrm{b}=\varepsilon_{h, \text { rup }}-\varepsilon_{h, \text { rup }} \frac{k_{c o n f}^{\prime}}{f_{c o}^{\prime}}, c=\frac{f_{c o}^{\prime}}{k_{c o n f}}\left(\varepsilon_{c o}+\varepsilon_{h, \text { rup }}+e^{\varepsilon_{h, r u p}}\right)
$$




\section{RESULTS AND DISCUSSION}

Three statistical evaluation criteria were used to assess the GEP models' performances: the correlation coefficient $(R)$, the root mean squared error (RMSE), and average absolute error $(A A E)$, defined as

$$
\begin{gathered}
R=\frac{\sum_{i=1}^{N}\left(m_{i}-\bar{m}_{i}\right)\left(p_{i}-\bar{p}_{i}\right)}{\sqrt{\sum_{i=1}^{N}\left(m_{i}-\bar{m}_{i}\right)^{2} \sum_{i=1}^{N}\left(p_{i}-\bar{p}_{i}\right)^{2}}} \\
R M S E=\sqrt{\frac{1}{N} \sum_{i=1}^{N}\left(m_{i}-p_{i}\right)^{2}} \\
A A E=\frac{1}{N} \sum_{i=1}^{N} \frac{\left|m_{i}-p_{i}\right|}{m_{i}} \times 100
\end{gathered}
$$

Where $N=$ number of samples; $m_{i}=$ measured value; $p_{i}=$ predicted value; and $\bar{m}_{i}$ and $\bar{p}_{i}=$ averages of measured and predicted values, respectively.

The statistical performance of the GEP model and existing models (Table 1) on the entire database are summarized in Table 2.

Table 2 Performances of ultimate axial strain of FRP-confined concrete models

\begin{tabular}{ccccccc}
\hline Model & \multicolumn{7}{c}{ Training } & & & \\
& \multicolumn{7}{c}{ Testing } \\
& \multicolumn{1}{c}{$R$} & $R M S E$ & $A A E$ & $R$ & $R M S E$ & $A A E$ \\
\cline { 2 - 7 } & & & & & \\
Ozbakkaloglu and Lim & 0.8744 & 0.0038 & 20.4363 & 0.8836 & 0.0054 & 21.4761 \\
Teng et al. & 0.8424 & 0.0049 & 33.3343 & 0.8801 & 0.0054 & 34.8783 \\
Fardis and Khalili & 0.3803 & 0.0117 & 62.1162 & 0.4328 & 0.0112 & 47.9206 \\
Berthet et al. & 0.8373 & 0.0043 & 22.2392 & 0.8187 & 0.0061 & 25.5959 \\
Tamuzs et al. & 0.8594 & 0.003 & 23.6353 & 0.8643 & 0.0056 & 26.5066 \\
Lim et al. & 0.8318 & 0.0044 & 22.5591 & 0.8698 & 0.0570 & 22.6110 \\
GEP & 0.925 & 0.0035 & 19.8791 & 0.9379 & 0.0050 & 19.0788 \\
& & & & & & \\
\hline
\end{tabular}


Table 2 shows that the GEP model produced the highest coefficient of determination and the lowest errors $(R=$ 0.9379 , RMSE $=0.0050$, and AAE $=19.0788)$ for the test data. Figure 3 and Figure 4 illustrate a comparison of the GEP results with those of existing models.

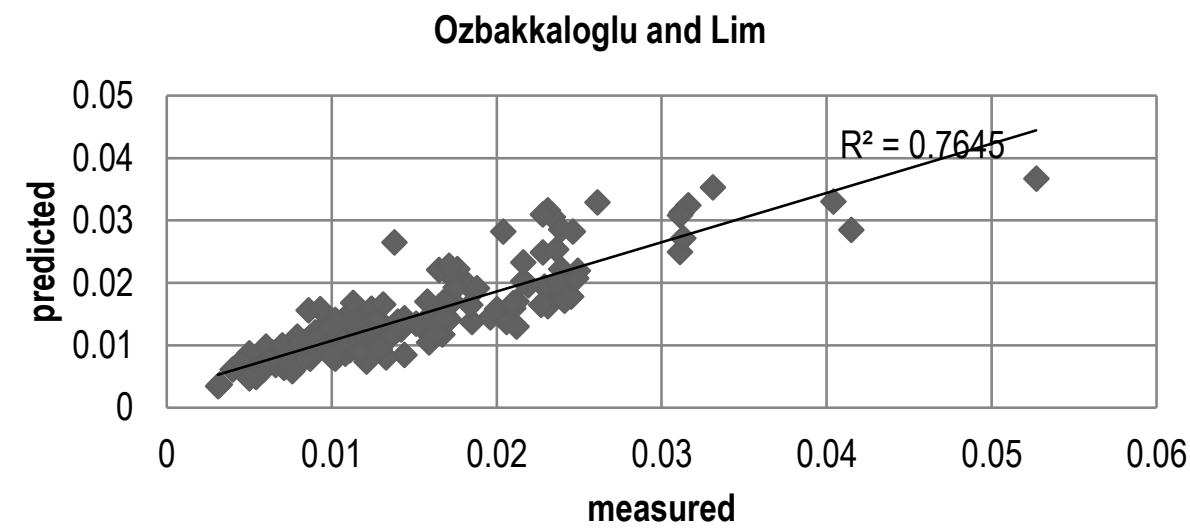

Teng et al.

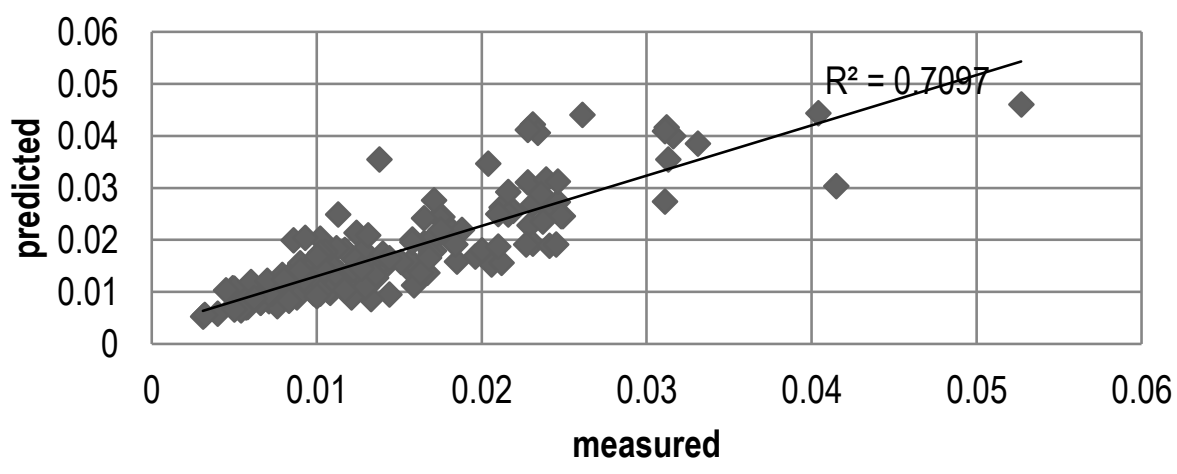

\section{Fardis and Khalili}

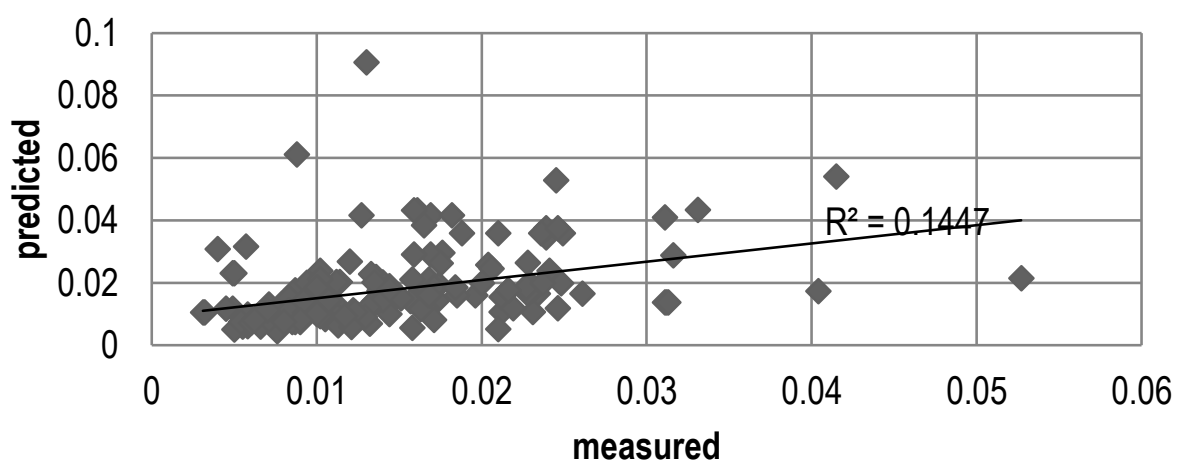




\section{Berthet et al.}

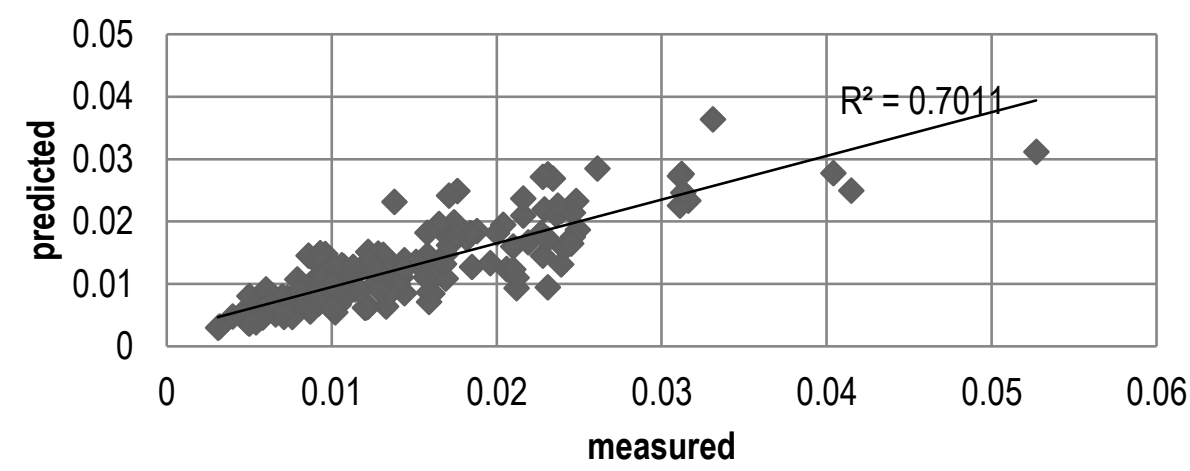

Tamuzs et al.

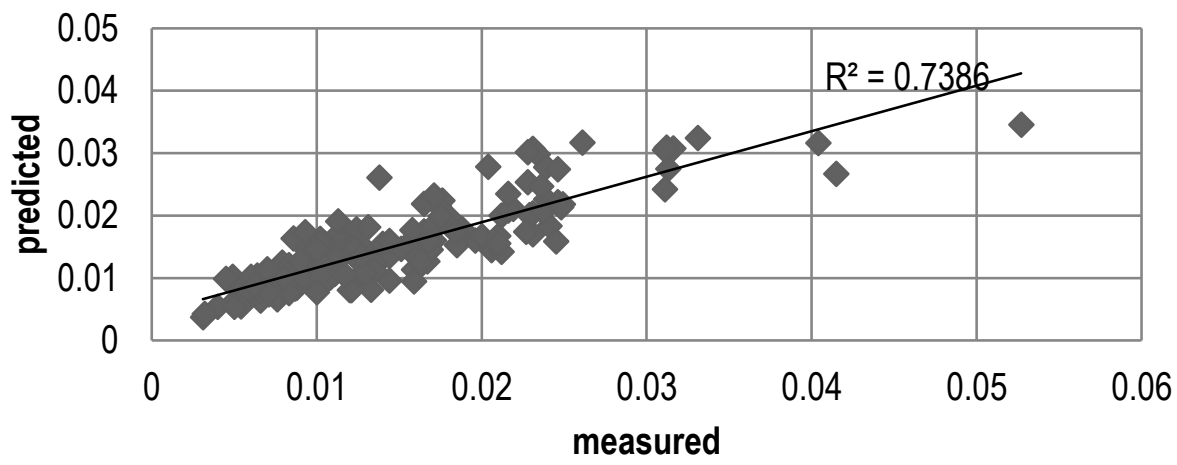

Lim et al.

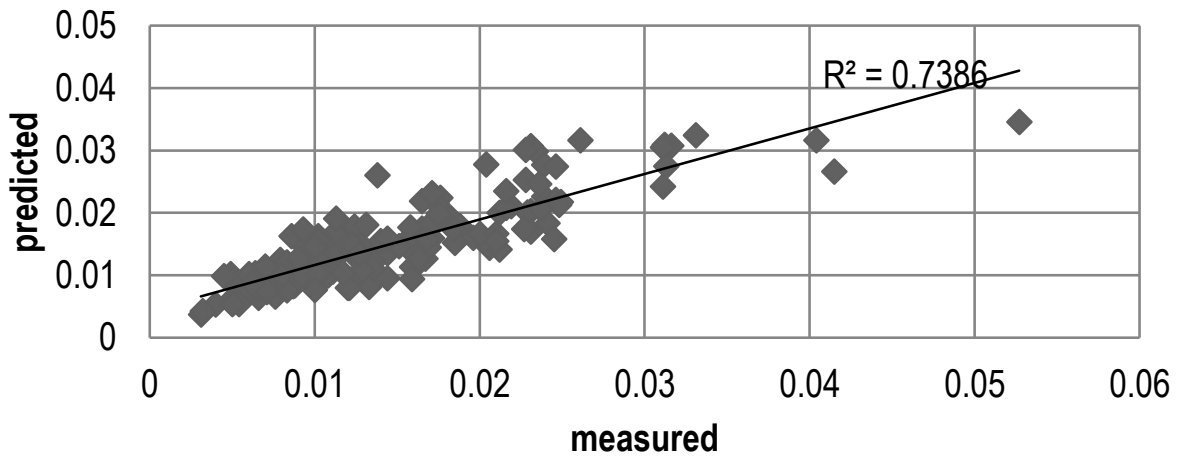




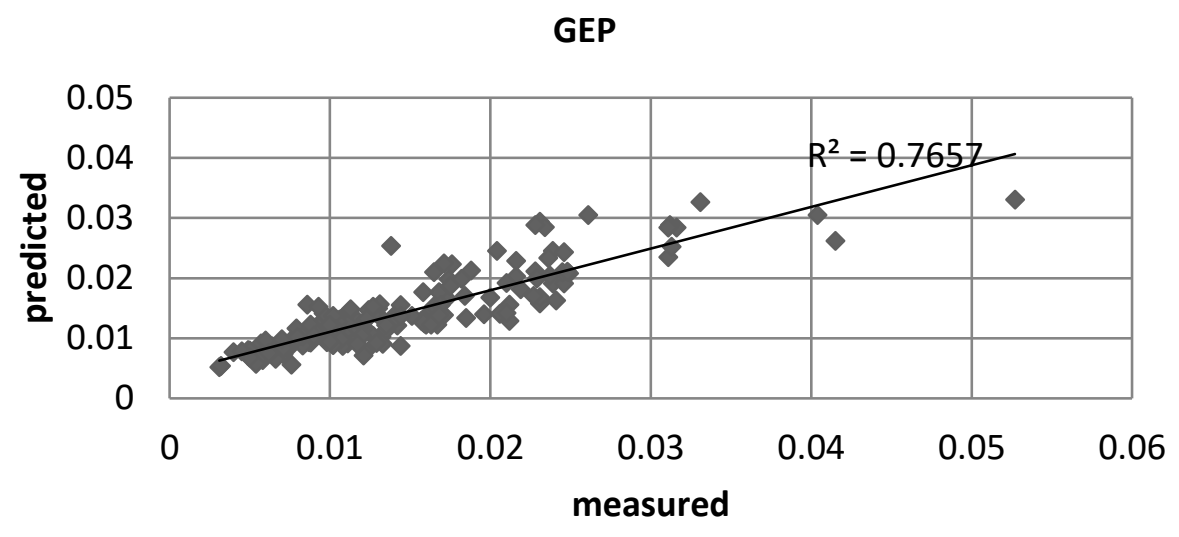

Figure 3 Comparison of GEP results with existing models for training data

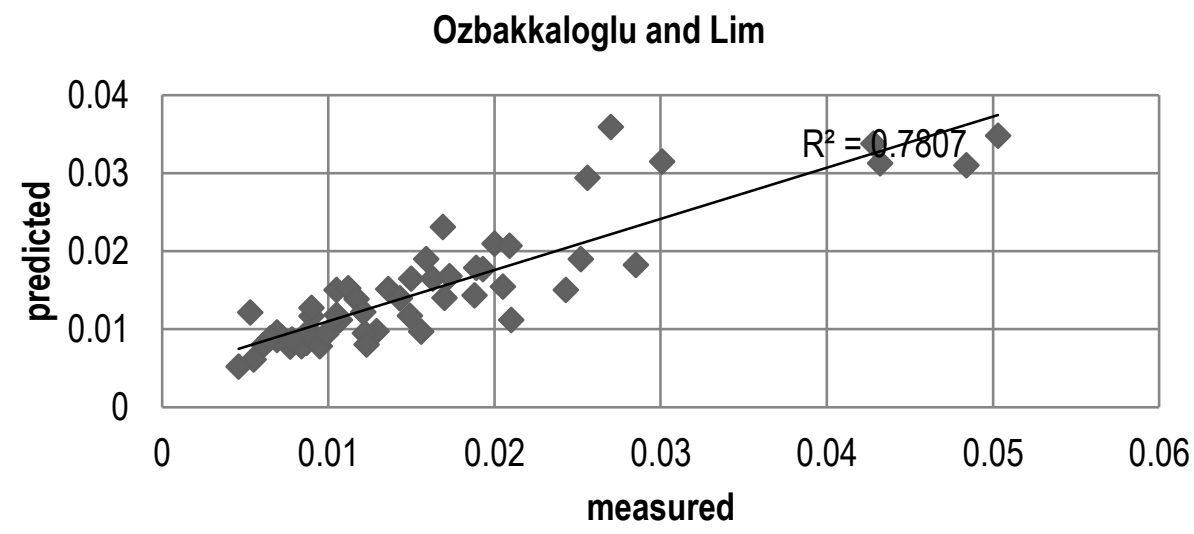

Teng et al.

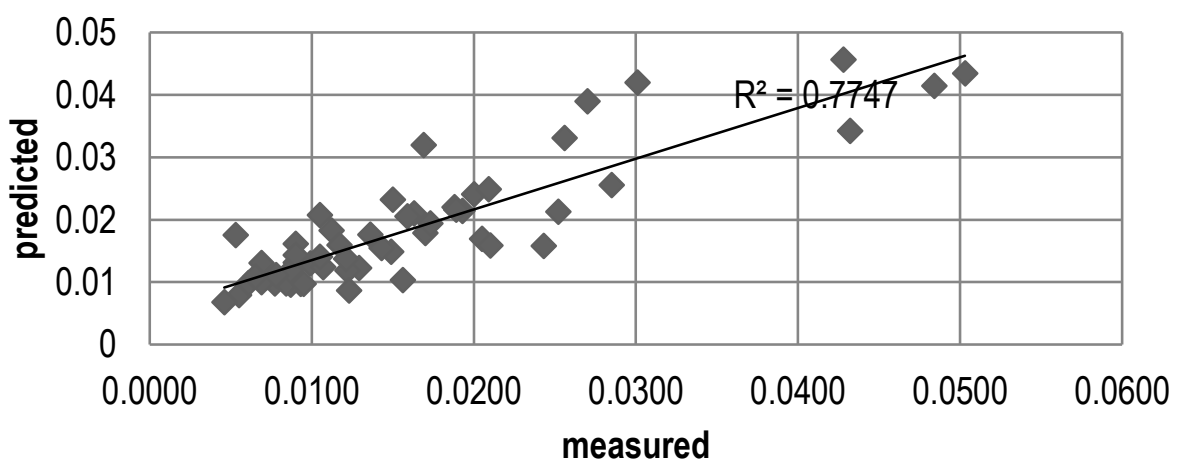




\section{Fardis and Khalili}

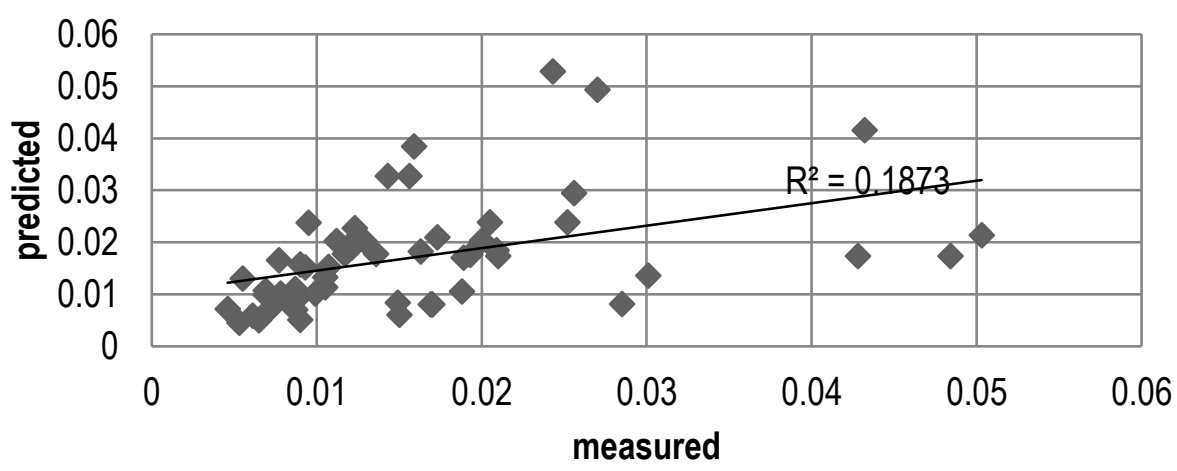

Berthet et al.

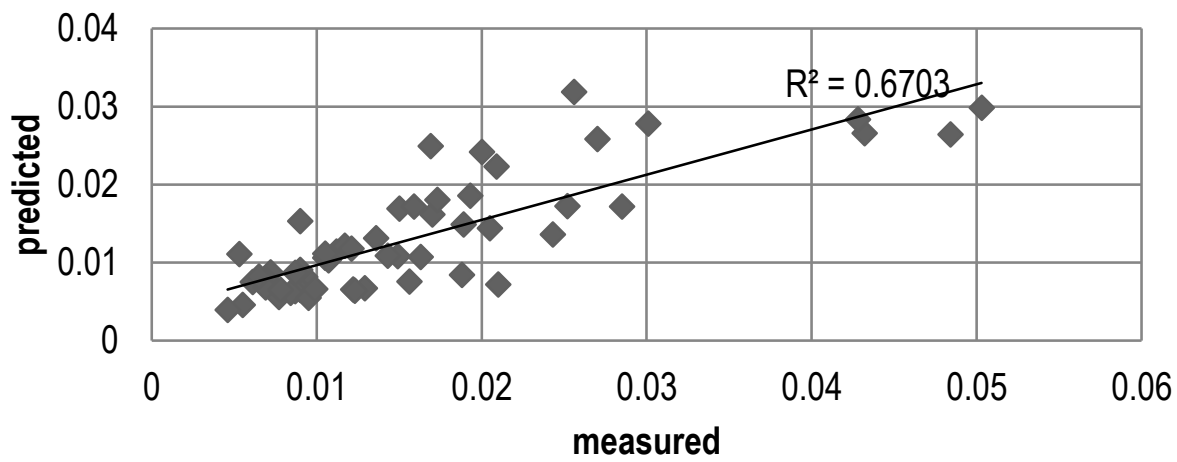

Tamuzs et al.

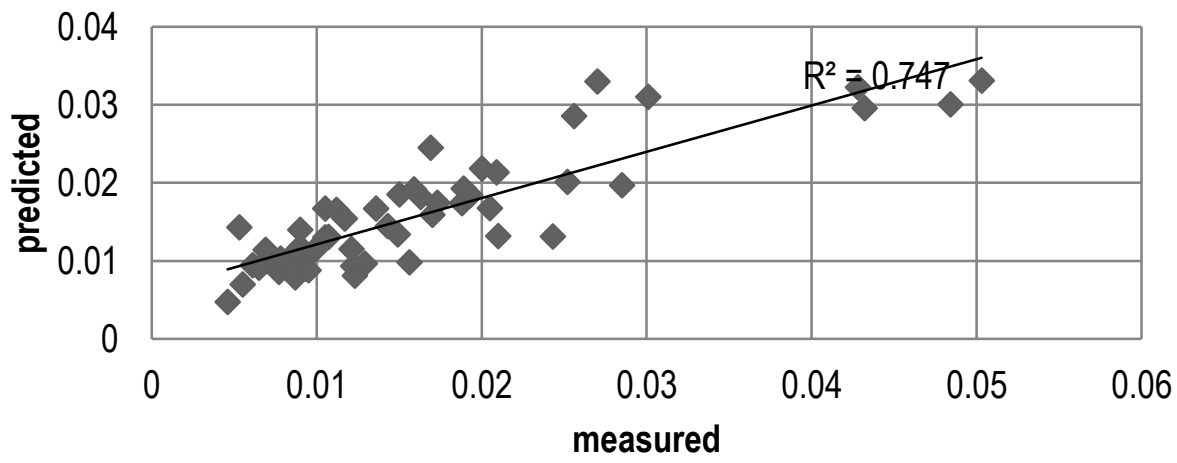




\section{GEP}

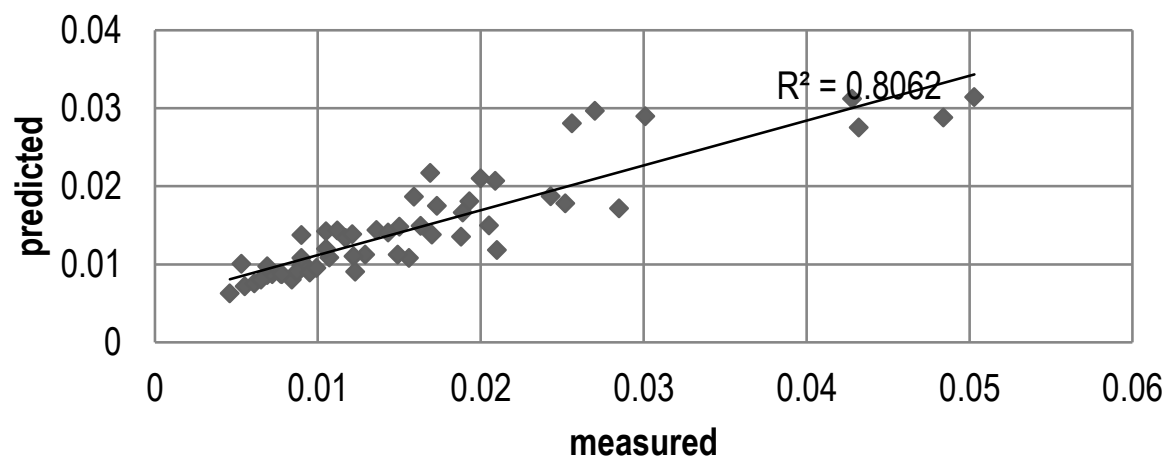

Figure 4 Comparison of GEP results with existing models for testing data

\section{CONCLUSIONS}

The application of the relatively new soft computing method of genetic programming to predict the axial strain of FRP-confined concrete was shown. A closed-form equation for the coefficients in order to predict the ultimate axial strain of FRP-confined concrete was derived using gene-expression programming from available data in the literature. The proposed equation produces better results compared to the existing equation when determining the axial strain. A constitutive relationship was developed to assess the ultimate axial strain of FRP-confined concrete using GEP. The proposed model is empirical and is based on experimental results gathered from the literature. The results based on the model reveal good agreement with the gathered experimental results. The performance of GEP to predict the ultimate axial strain of FRP-confined concrete was compared to five existing models. It was found that the GEP model is the best predictor of the experimental data.

\section{Acknowledgements}

This research was supported by a grant (18TBIP-C144315-01) from the Technology Business Innovation Program (TBIP) funded by the Ministry of Land, Infrastructure and Transport of the Korean government.

\section{References}

[1] Monti, G. and N. Nistico, Square and rectangular concrete columns confined by CFRP: Experimental and numerical investigation. Mechanics of Composite Materials, 2008. 44(3): p. 289-308. https://doi.org/10.1007/s11029-008-9021-1

[2] Realfonzo, R. and A. Napoli, Confining concrete members with FRP systems: Predictive vs design strain models. Composite Structures, 2013. 104: p. 304-319. https://doi.org/10.1016/j.compstruct.2013.04.031

[3] Bournas, D.A., et al., Textile-reinforced mortar versus fiber-reinforced polymer confinement in reinforced concrete columns. ACI Structural Journal, 2007. 104(6): p. 740-748.

[4] Harries, K.A., et al., Seismic retrofit of lap splices in nonductile square columns using carbon fiber-reinforced jackets. ACI Structural Journal, 2006. 103(6): p. 874-884.

[5] lacobucci, R.D., S.A. Sheikh, and O. Bayrak, Retrofit of Square Concrete Columns with Carbon FiberReinforced Polymer for Seismic Resistance. ACI Structural Journal, 2003. 100(6): p. 785-794.

[6] Realfonzo, R. and A. Napoli, Cyclic behavior of RC columns strengthened by FRP and steel devices. Journal of Structural Engineering, 2009. 135(10): p. 1164-1176. https://doi.org/10.1061/(ASCE)ST.1943$\underline{541 X .0000048}$ 
[7] Realfonzo, R. and A. Napoli, Results from cyclic tests on high aspect ratio RC columns strengthened with FRP systems. Construction and Building Materials, 2012. 37: p. 606-620. https://doi.org/10.1016/i.conbuildmat.2012.07.065

[8] Jiang, T. and J.G. Teng, Analysis-oriented stress-strain models for FRP-confined concrete. Engineering Structures, 2007. 29(11): p. 2968-2986. https://doi.org/10.1016/i.engstruct.2007.01.010

[9] Hu, J.W. and Y.I. Cho, Pilot Study for Investigating the Cyclic Response of the Recentering Bridge Bearing System Combined with the Friction Damper. Advances in Materials Science and Engineering, 2016. 2016. http://dx.doi.org/10.1155/2016/3701292

[10] Mansouri, I. and O. Kisi, Prediction of debonding strength for masonry elements retrofitted with FRP composites using neuro fuzzy and neural network approaches. Composites Part B: Engineering, 2015. 70: $p$. 247-255. https://doi.org/10.1016/i.compositesb.2014.11.023

[11] Mansouri, l., et al., Predicting behavior of FRP-confined concrete using neuro fuzzy, neural network, multivariate adaptive regression splines and M5 model tree techniques. Materials and Structures/Materiaux et Constructions, 2016. 49(10): p. 4319-4334. https://doi.org/10.1617/s11527-015-0790-4

[12] Mahdavi Jafari, M. and G.R. Khayati, Prediction of hydroxyapatite crystallite size prepared by sol-gel route: gene expression programming approach. Journal of Sol-Gel Science and Technology, 2018. 86(1): p. 112 125. https://doi.org/10.1007/s10971-018-4601-6

[13] Mansouri, I., R. Chacón, and J.W. Hu, Improved predictive model to the cross-sectional resistance of CFT. Journal of Mechanical Science and Technology, 2017. 31(8): p. 3887-3895. https://doi.org/10.1007/s12206017-0733-9

[14] Mansouri, I., J.W. Hu, and O. Kisi, Novel Predictive Model of the Debonding Strength for Masonry Members Retrofitted with FRP. Applied Sciences-Basel, 2016. 6: p. 1-13. https://doi.org/10.3390/app6110337

[15] Guven, A. and M. Gunal, Genetic programming approach for prediction of local scour downstream of hydraulic structures. Journal of Irrigation and Drainage Engineering, 2008. 134(2): p. 241-249. https://doi.org/10.1061/(ASCE)0733-9437(2008)134:2(241)

[16] Ebrahimzade, H., G.R. Khayati, and M. Schaffie, A novel predictive model for estimation of cobalt leaching from waste Li-ion batteries: Application of genetic programming for design. Journal of Environmental Chemical Engineering. https://doi.org/10.1016/j.jece.2018.05.045

[17] Gandomi, A.H., et al., Formulation of shear strength of slender RC beams using gene expression programming, part II: With shear reinforcement. Measurement: Journal of the International Measurement Confederation, 2017. 95: p. 367-376. https://doi.org/10.1016/j.measurement.2016.10.024

[18] Gandomi, A.H., et al., Genetic programming for experimental big data mining: A case study on concrete creep formulation. Automation in Construction, 2016. 70: p. 89-97. https://doi.org/10.1016/i.autcon.2016.06.010

[19] Ghaemi-Fard, M., H. Eskandari-Naddaf, and G.R. Ebrahimi, Genetic prediction of cement mortar mechanical properties with different cement strength class after freezing and thawing cycles. Structural Concrete, 2018. https://doi.org/10.1002/suco.201700196

[20] Güllü, H., A novel approach to prediction of rheological characteristics of jet grout cement mixtures via genetic expression programming. Neural Computing and Applications, 2017. 28: p. 407-420. https://doi.org/10.1007/s00521-016-2360-2

[21] Kiani, B., et al., New formulation of compressive strength of preformed-foam cellular concrete: An evolutionary approach. Journal of Materials in Civil Engineering, 2016. 28(10). https://doi.org/10.1061/(ASCE)MT.19435533.0001602

[22] Mahdavi Jafari, M. and G.R. Khayati, Prediction of hydroxyapatite crystallite size prepared by sol-gel route: gene expression programming approach. Journal of Sol-Gel Science and Technology, 2018. 86(1): p. 112125. https://doi.org/10.1007/s10971-018-4601-6

[23] Metin Kose, M. and C. Kayadelen, Effects of infill walls on RC buildings under time history loading using genetic programming and neuro-fuzzy. Structural Engineering and Mechanics, 2013. 47(3): p. 401-419. https://doi.org/10.1002/tal.535

[24] Youssef, M.N., M.Q. Feng, and A.S. Mosallam, Stress-strain model for concrete confined by FRP composites. $\begin{array}{lllll}\text { Composites Part } \quad \text { B: } & \text { Engineering, } 2007 . & 38(5-6): & \text { p. }\end{array}$ https://doi.org/10.1016/i.compositesb.2006.07.020 
[25] De Lorenzis, L. and R. Tepfers, Comparative study of models on confinement of concrete cylinders with fiberreinforced polymer composites. Journal of Composites for Construction, 2003. 7(3): p. 219-237. https://doi.org/10.1061/(ASCE)1090-0268(2003)7:3(219)

[26] Harries, K.A. and S.A. Carey, Shape and "gap" effects on the behavior of variably confined concrete. Cement and Concrete Research, 2003. 33(6): p. 881-890. https://doi.org/10.1016/S0008-8846(02)01085-2

[27] Lam, L. and J.G. Teng, Ultimate condition of fiber reinforced polymer-confined concrete. Journal of Composites for Construction, 2004. 8(6): p. 539-548. https://doi.org/10.1061/(ASCE)10900268(2004)8:6(539)

[28] Ozbakkaloglu, T. and J.C. Lim, Axial compressive behavior of FRP-confined concrete: Experimental test database and a new design-oriented model. Composites Part B: Engineering, 2013. 55: p. 607-634. https://doi.org/10.1016/i.compositesb.2013.07.025

[29] Ozbakkaloglu, T., J.C. Lim, and T. Vincent, FRP-confined concrete in circular sections: Review and assessment of stress-strain models. Engineering Structures, 2013. 49: p. 1068-1088. https://doi.org/10.1016/j.engstruct.2012.06.010

[30] Ozbakkaloglu, T. and D.J. Oehlers, Manufacture and testing of a novel FRP tube confinement system. Engineering Structures, 2008. 30(9): p. 2448-2459.

[31] Pessiki, S., et al., Axial behavior of reinforced concrete columns confined with FRP jackets. Journal of Composites for Construction, 2001. 5(4): p. 237-245. https://doi.org/10.1016/i.engstruct.2008.01.014

[32] Xiao, Y. and $\mathrm{H}$. Wu, Compressive behavior of concrete confined by carbon fiber composite jackets. Journal of Materials in Civil Engineering, 2000. 12(2): p. 139-146. https://doi.org/10.1061/(ASCE)08991561(2000)12:2(139)

[33] Teng, J.G., et al., Refinement of a design-oriented stress-strain model for FRP-confined concrete. Journal of Composites for Construction, 2009. 13(4): p. 269-278. https://doi.org/10.1061/(ASCE)CC.19435614.0000012

[34] Fardis, M.N. and H.H. Khalili, FRP-encased concrete as a structural material. Magazine of Concrete Research, 1982. 34(121): p. 191-202. https://doi.org/10.1680/macr.1982.34.121.191

[35] Berthet, J.F., E. Ferrier, and P. Hamelin, Compressive behavior of concrete externally confined by composite jackets: Part B: Modeling. Construction and Building Materials, 2006. 20(5): p. 338-347. https://doi.org/10.1016/i.conbuildmat.2005.01.029

[36] Tamuzs, V., et al., Behavior of concrete cylinders confined by a carbon composite 3. Deformability and the ultimate axial strain. Mechanics of Composite Materials, 2006. 42(4): p. 303-314. https://doi.org/10.1007/s11029-006-0040-5

[37] Lim, J.C., M. Karakus, and T. Ozbakkaloglu, Evaluation of ultimate conditions of FRP-confined concrete columns using genetic programming. Computers and Structures, 2016. 162: p. 28-37. https://doi.org/10.1016/i.compstruc.2015.09.005

Please cite this article as:

Mansouri, I, Azmathulla, H M, Wan Hu, J: Gene expression programming application for prediction of ultimate axial strain of FRP-confined concrete, Electronic Journal of the Faculty of Civil Engineering Osijek-e-GFOS, 16, pp. 64-76, https://doi.org/10.13167/2018.16.6 